УДК 37.016:811.111]:004.9

DOI:

Тетяна Цепко, старший викладач

Інститут філологї Київський національний університет імені Тараса Шевченка

\title{
ЗАСТОСУВАННЯ ІНТЕРАКТИВНИХ ТЕХНОЛОГІЙ У ВИКЛАДАННІ АНГЛІЙСЬКОї МОВИ
}

У статті проводиться диференціація понять традиційних технологій та інтерактивних. Розкривається поняття інтерактивних технологій, їх місие у системі навчання у закладах вищої освіти. Також розкривається значення інтерактивних технологій у викладанні англійської мови серед студентів. Приводяться класифікаиії інтерактивних технологій викладання. Подається структура заняття з англійської мови із застосуванням інтерактивних технологій. Розкривається суть процесу інтеріоризації - як механізму, завдяки якому інтерактивні технології стають ефективними. Оглядаються найбільш ефективні інтерактивні технології у навчальному процесі викладання англійської мови, серед яких такі: метод сценарію, метод навчання по станціям, кейз-стаді, технологія проектів, мозковий штурм. А також проводиться огляд інтерактивних ігор, які рекомендується застосовувати при викладанні англійської мови для розширення іноземного словникового запасу студентів.

Ключові слова: інтерактивні технології; традиційні технології; мозковий штурм; технологія проектів; кейз-стаді; технологія сиенарію; технологія станцій; інноваційне навчання; інтеріоризація.

Jim. 10.

Tetyana Tsepko, Senior Lecturer Institute of Philology Kyiv Taras Shevchenko National University

\section{APPLICATION OF INTERACTIVE TECHNOLOGIES IN TEACHING ENGLISH}

Learning English today is more than ever urgent in connection with the process of Ukraine's joining the European space. A large number of Ukrainians are interested in learning a foreign language, especially students, as it provides plenty of opportunities and benefits on the way to building a career and building themselves as a competitive specialist. However, socio-economic changes and information development require a revision of the established traditional teaching system. In general, the concept of interactive teaching methods is based on the psychological phenomenon - interiorization, the essence of which lies in the unity of knowledge and activity.

The research paper deals with the differentiation of concepts of traditional and interactive technologies. The concept of interactive technologies, their place in the teaching system of higher education institutions is revealed. The importance of interactive technologies in teaching English to students is also revealed. Interactive teaching technologies are classified. The structure of English language classes with the use of interactive technologies is presented. The essence of the process of interiorization as a mechanism through which interactive technologies become effective is revealed. The most effective interactive technologies in the process of teaching English are reviewed, which include: scenario method, method of training on stations, case study, project technology, brainstorms. There is also an overview of interactive games that are recommended for use in teaching English to expand the foreign vocabulary of students. The use of interactive technologies in teaching English plays an important role, they improve the language competences of students, develop their ability to take collective and independent decisions, activate research skills, increase motivation to learn a foreign language, stimulate creative and intellectual solutions, and provide intensive language practice of students.

Keywords: interactive technologies; traditional and interactive technologies; scenario method; method of training on stations; case study; project technology; brainstorming.

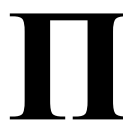

остановка проблеми у загальному вигляді та її зв'язок із важливими науковими чи практичними завданнями. Вивчення англійської мови на сьогоднішній день є як ніколи актуальним в зв'язку з процесом входженням України в європейський простір. Велика кількість населення України зацікавлена у вивченні іноземної мови, особливо студенти, оскільки це дає велику кількість можливостей та переваг на шляху до побудови кар'єри та конструювання себе як конкурентоспроможного фахівця. Проте соціально-економічні зміни та інформаційний розвиток вимагають перегляду сформованої традиційної системи викладання. Оскільки існують суперечності між необхідністю освоєння студентами нових сфер знань, зокрема вивчення іноземної мови і труднощами в їх освоєнні в повному обсязі. Тому, важливими питаннями $\epsilon$ поліпшення професійної підготовки викладачів англійської мови, оновлення науково-методичної системи освіти, вдосконалення форм, методів та 
технологій викладання, скорочення розриву між навчальним процесом та майбутньою професійною діяльністю, перетворення студента у суб'єкта власної діяльності.

У зв'язку з цим актуальними є питання модифікації та вдосконалення технологій викладання англійської мови серед студентів. Адже тільки фахівець 3 якісною освітою зможе стати активним учасником економічного, соціального і культурного розвитку суспільства.

Тому, наразі в умовах викладання англійської мови існує потреба у організації навчального процесу таким чином, щоб створити умови для творчого мислення, дослідницької роботи, формування інтересу до майбутньої спеціальності.

В сучасних закладах вищої освіти користуються застарілими технологіями викладання, що передбачає академічний виклад теми викладачем, та відтворення цього матеріалу студентом. Такий підхід зумовлює зниження інтересу, мотивації, ентузіазму у вивченні англійської мови. Ми не вважаємо, що традиційні технології викладання слід вилучити взагалі, а стверджуємо, що їх слід доповнити інноваційними інтерактивними технологіями. Крім того, існує проблема зниження концентрації уваги, тобто через деякий час стає важко зосереджувати увагу на одноманітній діяльності. Тому, вважаємо, що у викладанні англійської мови буде доречним та більш ефективним доповнення традиційних методів інтерактивними.

Аналіз останніх досліджень і публікацій. Проблема застосування інтерактивних технологій розглядалась у низки вітчизняних вчених та методистів: С. Ніколаєва, Ю. Кравченко, І. Дичківська, У. Науменко. Такі методисти як С. Ніколаєва, О. Бігич, Н. Бориско, О. Борецька, вважають, що “... вивчення іноземної мови - це складний, процес, який вимагає регулярної і творчої діяльності не тільки для студентів, а й для викладача" $[9,112]$. Даний процес розглядається фахівцями як один із основних напрямів упровадження іноземної мови в суспільне середовище. Сучасному викладачу важливо знати новітні навчальні техніки та прийоми викладання, щоб оптимально підібрати той чи інший метод відповідно до рівня знань, потреб та інтересів студентів.

Ю.О. Кравченко говорить: “Інтерактивні технології навчання іноземним мовам створюють необхідні передумови як для розвитку мовленнєвої компетенції студентів, так і для формування умінь приймати колективні та індивідуальні рішення 3 метою виховання активних громадян суспільства" $[2,89]$.

У. Науменко стверджує, "Вища школа має бути не підготовкою до життя, вища школа має бути життям. Досягнути цього можливо за рахунок інноваційного підходу, створюючи інтерактивне середовище" [6, 119].

I. Дичківська вважає, що "Освіта $\epsilon$ ознакою сучасності, вона не $є$ незмінним феноменом, вона має реагувати на реалії, суспільні тенденції та перспективи. Однак, традиційні методи навчання, направленні на передачу знань, умінь, навичок не встигають за їх нарощуванням" $[1,34]$.

О. Пометун виділяє традиційні (стандартні) технології викладання, де викладач ставить собі за мету передати студентам осмислену та диференційовану ним інформацію, а завдання студентів засвоїти та відтворити інформацію. Тобто викладач англійської мови доносить певні знання з іноземної мови: граматику, нову лексику, та інше, а студенти після цього мають запам'ятати та відтворити інформацію. Викладач виступає тут у якості контролера, а студент отримує пасивну роль.

Інтерактивні технології за О. Пометун, “...передбачають не просто запам'ятовування знань від педагога, але й отримання їх в ході власної активності”. Таким чином інтерактивні технології передбачають самостійність у відкритті, здобутті та конструюванні знань, а також застосування отриманих знань у новій ситуації. В цьому випадку викладач виступає в ролі організатора процесу навчання, лідера групи, а студент отримує активну роль $[8,7]$.

Мета статті. Визначити роль інтерактивних технологій в навчальній діяльності та запропонувати найбільш ефективні інтерактивні технології у викладанні англійської мови.

Виклад основного матеріалу. Слово інтерактив (пер. з англійської inter - “взаємний”, act - “діяти”) означає взаємодію. Інтерактивний метод - це спосіб взаємодії зі студентами через бесіду, діалог. Під “інтерактивним навчанням" розуміється навчання, засноване на спільній комунікації, навчання за допомогою діалогу, в наступних форматах: розмова, діалог, обговорення, спільні дії.

За Ю. Кравченко, “Інтерактивною технологією називають ту, яка ставить студента у положення творця та активного учасника навчального процесу" $[2,90]$.

Взагалі концепція інтерактивних методів навчання заснована на психологічному феномені - інтеріоризації, суть якої полягає в єдності пізнання і діяльності. В контексті даної теорії процес засвоєння знань відбувається шляхом інтеріоризації, тобто засвоєння знань відбувається в результаті виконання студентами системи дій [10]. 
Значення інтерактивних технологій у викладанні англійської мови важко переоцінити, вони покращують мовленнєві компетенції студентів, формують уміння приймати колективні та самостійні рішення, активізують дослідницькі уміння, підвищують мотивацію до вивчення іноземної мови, стимулюють проявлення творчих та інтелектуальних рішень, забезпечують інтенсивну мовленнєву практику студентів. В такому випадку студент є рівноправним, рівнозначним суб'єктам навчання разом 3 педагогом.

О. Пометун визначила класифікацію інтерактивних технологій залежно від мети та форми діяльності:

- коопероване навчання;

- колективно-групове навчання;

- ситуативне моделювання;

- технологія дискусійних питань [9, 49].

До того ж виділяють такі типи інтерактивних технологій за формою роботи:

- індивідуальна;

- парна;

- групова.

Також методисти поділяють інтерактивні технології на групові, які передбачають роботу у малих групах та фронтальні, які включають роботу всього колективу студентів.

У проведенні інтерактивного заняття варто дотримуватися структури, тому Ю. Кравченко подає наступну структуру заняття з англійської мови із застосуванням інтерактивних технологій:

1) Підготовчий етап - включає організацію заняття, підготовку необхідних матеріалів, написання конспектута планузаняття, вирішення місця проведення та інше.

2) Етап вступу. На даному етапі відбувається пояснення правил, мети, завдань, хід заняття та інше інформування студентів.

3) Етап проведення передбачає власне проведення певних інтерактивних технологій викладачем, і виконання студентами.

4) Етап рефлексії. На цьому етапі викладач із студентами обговорює результати завдання, досягнення цілей, та оцінювання отриманих результатів діяльності $[2,91]$.

Сучасна педагогіка нараховує велику кількість інтерактивних технологій, які можна використовувати при викладанні англійської мови у закладах вищої освіти серед студентів. Наведемо приклади інтерактивних технологій: внутрішні (зовнішні) кола (inside / outside circles); навчання з комп'ютерною підтримкою (CALL), мозковий штурм (brain storm); технологія сценарію (storyline method), технологія групових пазлів, читання зигзагом (jigsaw reading); обмін думками (think-pair-share); парні інтерв'ю (pair-interviews), технологія каруселі, навчання по станціях, рольові ігри, “кейз-стаді" [3, 8$]$.

Розглянемо детальніше найбільш ефективні для застосування техніки. Технологія кейз-стаді передбачає роботу над проблемними ситуаціями: викладач пропонує проблемну ситуацію, студенти розглядають, аналізують, пропонують свої варіанти розв'язання проблеми. Наприклад, можна запропонувати такі теми для дискусії: "Leadership as a political phenomenon", "Conflicts in world politics", "Global and regional political processes".

Метод сценарію (storyline method) заснований на поєднанні запланованих навчальних змістів, 3 інтересами та ідеями студентів. В такому разі студент отримує можливість самостійно обирати яким чином пройде частина або ціле заняття 3 англійської мови. Наприклад, студенти можуть запропонувати, що спочатку виконають завдання, передбачені викладачем, а потім проведуть дискусію на обрану тему, після цього попрацюють у парах [4, 36].

Метод навчання по станціях. С схожим 3 попереднім - студенти отримують навчальний план, де позначені обов'язкові та вибіркові завдання, та отримують можливість розподілити час, послідовність та форму виконання завдання. Таким чином вони самостійно регулюють власну навчальну діяльність [5, 41].

Одним із дієвих інтерактивних технологій $\epsilon$ “мереживна пилка", розроблений Е. Аронсоном у 1978 р. В рамках даної техніки студенти передають один одному інформацію, яку засвоїли від викладача. Ефективність цієї технології у тому, що виступаючи у ролі викладача, студент більш ефективно засвоює матеріал, оскільки навчаючи, ми краще запам'ятовуємо.

Технологія “Зустріч експертів” (Expert Groups) полягає у наступних діях: студенти об'єднуються у групи, кожен із них опрацьовує певний матеріал, а далі доносить його до інших учасників групи, які занотовують та запам'ятовують наданий матеріал. Дана технологія дає змогу швидко засвоїти матеріал та отримати цілісне уявлення про тему, яка вивчається.

Інтерактивна технологія “Обери позицію” пропонує дискусійну тему, а студенти мають обрати власну позицію, аргументуючи свій вибір.

Технологія “Шкала думок” полягає у застосуванні науково обгрунтованих концепцій та фактів на англійській мові, а також використання власного досвіду в умовах дискусії [7, 113].

Технологія проектів ("Project"), є наразі 


\section{ЗАСТОСУВАННЯІНТЕРАКТИВНИХ ТЕХНОЛОГЙ̆У ВИКЛАДАННІ АНГЛЙСЬКОӤ МОВИ}

найбільш розповсюдженою. Під технологією проектів розуміється система навчання, при якій студент набуває знання і вміння в процесі самостійного планування та виконання, що поступово ускладнюються, практичних завдань - проектів. Основною метою використання методу проектів в навчанні іноземної мови $\epsilon$ можливість в оволодінні студентами комунікативної компетенції, тобто практичному оволодінню іноземною мовою. Дана технологія створює можливості для прояву комунікативних умінь високого рівня у всіх видах мовленнєвої діяльності: аудіювання, говоріння, листування, читання, переказ в межах певної теми; оволодіння учням лексикою по темі в якості необхідної основи для оформлення мовленнєвих умінь; придбання знань про культуру країн мови, що вивчається.

Крім того, проектне навчання сприяє: підвищенню особистої впевненості студентів, розвиває комунікабельність та вміння співпрацювати; активізує критичне мислення, вміння шукати шляхи вирішення проблеми; розвиває в студентів дослідницькі вміння.

Розрізняють такі типи проектів:

- дослідні;

- творчі;

- рольової-ігрові;

- інформаційні;

- практико-орієнтовані.

Серед інтерактивних технологій викладання має своє місце і мультимедійний комплекс, який передбачає використання інтерактивних дошок, комп'ютера, проектора. Дана технологія відповідає принципу наочності у навчанні, тому ефективність навчання буде підвищуватись. Формами роботи тут $\epsilon$ презентації, демонстрування та моделювання ситуацій. Мультимедійний комплекс стимулює творчий потенціал, підвищує мотивацію до навчання. Однак необхідно пам'ятати, що комп'ютерні технології не визначають зміст навчання - вони $€$ лише ефективним засобом навчання іноземної мови. Використання інформаційних технологій має мотивуватися їх необхідністю, а не бути даниною моді $[8,53]$.

Окремою інтерактивною технологією є метод пізнавальних ігор, в яких відбувається моделювання життєвих ситуацій, взаємодії, стосунків. Крім навчального значення гра сприяє подоланню невпевненості, розкриттю особистостей студентів, прояву творчості та власних можливостей, розвитку комунікативних навичок.

Розглянемо деякі різновиди ігор, які передбачають розширення словникового запасу англійської мови.

1) Grabaminute - в ході гри студенту надається картка 3 певним предметом або терміном, а він має за одну хвилин представити цей термін. Можна використовувати термінологію за професійним спрямуванням. Викладачем оцінюється повнота, зв'язність, граматика та лексика.

2) Anitemdescription - в цій грі пропонується описати термін чи слово, не називаючи його. В цьому випадку активну роль грає і учасник, який описує слово і група, яка відгадує. Викладач оцінює словниковий запас та граматику.

3) Chainstory - гра полягає у продовженні історії попереднього студента. Тобто один за одним студенти продовжують одну й ту саму історію. Викладач оцінює словниковий запас та граматику англійської мови.

4) “What? Where? When?” студенти діляться на групи, отримують запитання, кожна група за обмежений час проводить обговорення англійською мовою. Така гра дозволяє активізувати словниковий запас, інтелектуальні процеси, направленість на вирішення нестандартних ситуацій, та підвищує мотивацію. Викладач оцінює словниковий запас, яким користуються студенти, кількість помилок, граматику.

5) Ще один варіант гри у формі мозкового штурму. Тут викладачем подається проблемне питання, яке потребує рішення, а всі без виключення студенти в свою чергу, висловлюють свій варіант розв'язання, яким би абсурдним він не був [6, 119].

Висновки. Таким чином ми з'ясували, що наразі більшість викладачів користується стандартними технологіями при викладанні англійської мови, тому вважаємо, що більш доцільним та ефективним буде розширити інструментарій викладачів інтерактивними технологіями, оскільки вони сприяють кращому засвоєнню матеріалу, підвищенню інтересу та мотивації у студентів. Слово інтерактив (пер. 3 англійської inter - “взаємний”, act - “діяти”) означає взаємодію під “інтерактивним навчанням” розуміється навчання, засноване на спільній комунікації, навчання за допомогою діалогу, в наступних форматах: розмова, діалог, обговорення, спільні дії. Інтерактивні технології передбачають створення найбільш сприятливих умов для розкриття кожного студента, засвоєння матеріалу (лексики та граматики англійської мови) студентами у формі гри, взаємодія відбувається на рівнях: викладач-студент, студент-студент, студент-група. 
Наразі існує велика кількість інтерактивних технологій, кожен викладач англійської мови повинен самостійно підбирати ті технології, які підходять для застосування 3 конкретними студентськими колективами.

Використання інтерактивних технологій у викладанні англійської мови має важливу роль, вони покращують мовленнєві компетенції студентів, формують уміння приймати колективні та самостійні рішення, активізують дослідницькі уміння, підвищують мотивацію до вивчення іноземної мови, стимулюють проявлення творчих та інтелектуальних рішень, забезпечують інтенсивну мовленнєву практику студентів. Тому, зважаючи на вищесказане, вважаємо за доцільне доповнити стандартні (традиційні) технології викладання інноваційними, а саме інтерактивними.

\section{ЛІТЕРАТУРА}

1. Дичківська І. М. Інноваційні педагогічні технології: навч. посібник. - К.: Академвидав, 2004. - 352 c.

2. Кравченко Ю.О. Про деякі інтерактивні методи назаняттях англійської мови / Ю.О. Кравченко // Молодий вчений. - 2017. - С. 89-117.

3. Крамаренко С.Г. Інтерактивні техніки навчання як засіб розвитку творчого потенціалу учнів / С. Г. Крамаренко // Відкритий урок. -2002. - № 5-6. - С.7-10.

4. Кошечко Н. Інноваційні освітні технології навчання та викладання у вищій школі / Н. Кошечко. // Педагогіка. - 2015. - С. 35-38.

5. Кошечко Н.В. Методика викладання у вищій школі: навч. посібник. - Ніжин: НДУ ім. М. Гоголя, 2013. - 115 c.

6. Науменко У. В. Інноваційні методи навчання англійської мови у вищій школі в умовах модернізації / У. В. Науменко // Молодий вчений. - 2018. - C. 118-122.

7. Пометун О., Пироженко Л. Сучасний урок. Інтерактивні технології навчання. - К., 2004. - 192 с.

8. Пометун О.І. Інтерактивні технології навчання: теорія, практика, досвід: метод. посібник / O.І. Пометун, Л.В. Пироженко. - К.: А.П.Н., 2002. - 136 c.

9. Методика навчання іноземних мов і культур: теорія і практика: підручник для студ. класичних, педагогічних і лінгвістичних університетів/О.Б. Бігич, Н.Ф. Бориско, Г.Е. Борецька та ін. / за заг. ред. С.Ю. Ніколаєвої. - К.: Ленвіт, 2013. - 590 с.

10. Інтерактивне навчання як новітній підхід до організації навчального процесу в школі [Електронний ресурс]. - Режим доступу: http:// www.ipedahohika.com/lirefs-181-2.htm

\section{REFERENCES}

1. Dychkivska, I. M. (2004). Innovatsiini pedahohichni tekhnolohii: navch. posibnyk [Innovative Pedagogical Technologie: Teaching Aid]. Kyiv: Akademvydav, 352 p [in Ukrainian].

2. Kravchenko, Yu. O. (2017). Pro deiaki interaktyvni metody na zaniattiakh anhliiskoi movy [On Some Interactive Methods at English lessons]. Young Scientist, pp. 89-117. [in Ukrainian].

3. Kramarenko, S.H. (2002). Interaktyvni tekhniky navchannia yak zasib rozvytku tvorchoho potentsialu uchniv [Interactive Teaching Techniques as a Means of Developing the Creative Potential of Students]. Open lesson, no. 5-6, pp. 7-10. [in Ukrainian].

4. Koshechko, N. (2015). Innovatsiini osvitni tekhnolohii navchannia ta vykladannia u vyshchii shkoli [Innovative Educational Technologies of Learning and Teaching in Higher School]. Pedagogy, pp. 35-38. [in Ukrainian].

5. Koshechko, N. V. (2013). Metodyka vykladannia $u$ vyshchii shkoli: navch. posibnyk [Methodology of Teaching in Higher School: Teaching Aid]. Nizhyn: Nizhyn State University named after M. Hohol, 115 p. [in Ukrainian].

6. Naumenko, U. V. (2018). Innovative Methods of Teaching English at Higher School under the Conditions of Modernization [Innovatsiini metody navchannia anhliiskoi movy u vyshchii shkoli v umovakh modernizatsii]. Young Scientist, pp. 118122. [in Ukrainian].

7. Pometun, O. \& Pyrozhenko, L. (2004). Modern Lesson. Interactive Learning Technologies [Suchasnyi urok. Interaktyvni tekhnolohii navchannia]. Kyiv, 192 p. [in Ukrainian].

8. Pometun, O. I. (2002). Interactive Learning Technologies: Theory, Practice, Experience: Teaching Aid [Interaktyvni tekhnolohii navchannia: teoriia, praktyka, dosvid: metod. posibnyk]. Kyiv: A.P.N., 136 p. [in Ukrainian].

9. Bigych, O. B., Borysko, N. F., Boretska, H. E. et al. (2013). Methods of Teaching Foreign Languages and Cultures: Theory and Practice: textbook for Students of Classical, Pedagogical and Linguistic Universities [Metodyka navchannia inozemnykh mov i kultur: teoriia i praktyka: pidruchnyk dlia stud. klasychnykh, pedahohichnykh i linhvistychnykh universytetiv]. (Ed.). S.Yu. Nikolaeva. Kyiv: Lenvit, 590 p. [in Ukrainian].

10. Interaktyvne navchannia yak novitnii pidkhid do orhanizatsii navchalnoho protsesu v shkoli [Interactive Learning as the Newest Approach to Organizing the Educational Process at School] [Electronic resource]. Available at: http://www.ipedahohika.com/lirefs-1812.htm [in Ukrainian].

Стаття надійшла до редакції 09.11.2018 